\title{
In vitro Antioxidant and Antidiabetic Activities of Leaf and Flower Extracts from Bombax ceiba
}

\author{
Nurarat Kriintong, Teeraporn Katisart \\ Department of Biology, Faculty of Science, Mahasarakham University, Kantharawichai, Maha Sarakham, Thailand
}

\begin{abstract}
Context: Bombax ceiba is belonging to the family Bombacaceae. Dried stamen of this plant is used as vegetable and food ingredients for people in the Northern part of Thailand. There are very few reports on the biological activities in this plant, especially the flower parts. Objectives: The present study aimed to demonstrate the phytochemical screening and in vitro antioxidant and antidiabetic activities of crude extracts from B. ceiba. Materials and Methods: The leaf and flower part of $B$. ceiba were extracted using different solvents including water, $50 \%$ ethanol, and $95 \%$ ethanol. The phytochemical constituents were determined using standard qualitative methods. Total phenolic content (TPC) and total flavonoid content (TFC) were analyzed by colorimetric methods. 2,2-diphenyl-1-picrylhydrazyl (DPPH) radical scavenging assay, 2,2-azino-bis-(3-ethylbenzothaizoline-6-sulphonate (ABTS) assay, and ferric reducing antioxidant power (FRAP) assay were used to investigate the in vitro antioxidant and antidiabetic activities of the extracts. For in vitro antidiabetic activities, $\alpha$-glucosidase and $\alpha$-amylase inhibitory effects were tested. Results: Phytochemical screening indicated the presence of alkaloids, flavonoids, coumarins, saponins, tannins, terpenoids, and cardiac glycosides in this plant. The highest TPC and TFC were found in $95 \%$ ethanol flower extract $(2.73 \pm 0.064 \mathrm{mg}$ gallic acid equivalent $/ \mathrm{g}$ and $28.25 \pm 2.33 \mathrm{mg}$ quercetin equivalent $/ \mathrm{g}$, respectively.). However, the highest antioxidant activity (DPPH and ABTS + assay) was found in $95 \%$ ethanol leaf extract $(0.012 \pm 0.0003,0.009 \pm 0.0005 \mathrm{mg} / \mathrm{mL}$, respectively.) and FRAP assay was found in 95\% ethanol flower extract $(349.27 \pm 35.16 \mathrm{mg}$ trolox equivalent/g). The highest $\alpha$-glucosidase and $\alpha$-amylase inhibitory activities were found in $95 \%$ ethanol flower extract $(0.001 \pm 0.0012$ and $0.0002 \pm 0.0001 \mathrm{mg} / \mathrm{mL}$, respectively). Conclusion: The crude extracts from $B$. ceiba showed the potent in vitro antioxidant and antidiabetic activities, especially the flower extracts. These findings confirm the ethnobotanical uses of $B$. ceiba as food and medicinal plants. Further studies on biological and pharmacological activities of this plant in the animal model and clinical trials must be carried out to confirm the use in medical aspects.

Key words: Bombax ceiba leaf and flower extracts, in vitro antidiabetic inhibitory activity, in vitro antioxidant activity, phytochemical screening
\end{abstract}

\section{SUMMARY}

- Phytochemical constituents revealed the presence of alkaloids, flavonoids, coumarins, saponins, tannins, terpenoids, and cardiac glycosides in Bombax ceiba extracts. The highest total phenolic content and total flavonoid content were found in 95\% ethanol flower extract. The highest antioxidant activity (2,2-diphenyl-1-picrylhydrazyl and 2,2-azinobis-(3-ethylbenzothaizoline-6-sulphonate + assay) was found in $95 \%$ ethanol leaf extract and ferric reducing antioxidant power assay was found $95 \%$ ethanol flower extract. The highest $\alpha$-glucosidase and $\alpha$-amylase inhibitory activities were found in 95\% ethanol flower extract. The crude extracts from $B$. ceiba showed the potent in vitro antioxidant and antidiabetic activities, especially the flower extracts. These findings confirm the ethnobotanical uses of $B$. ceiba as food and medicinal plants. Further studies on biological and pharmacological activities of this plant in the animal model and clinical trials must be carried out to confirm the use of this plant in medical aspects.

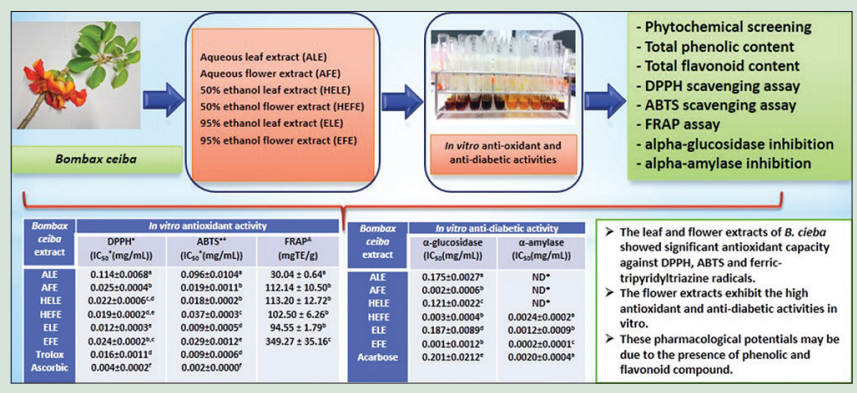

Abbreviations used: ALE: Aqueous leaf extract; AFE: Aqueous flower extract; HELE: $50 \%$ ethanol leaf extract; HEFE: $50 \%$ ethanol flower extract; ELE: 95\% ethanol leaf extract; EFE: 95\% ethanol flower extract; DPPH: 2,2-diphenyl-1-picrylhydrazyl; ABTS: 2,2-azino-bis-(3-ethylbenzothaizoline-6-sulphonate; FRAP: Ferric reducing antioxidant power; TPC: Total phenolic content; TFC: Total flavonoid content.

\section{Correspondence:}

Dr. Teeraporn Katisart,

Department of Biology, Faculty of Science,

Mahasarakham University, Talat, Maha Sarakham, 44150, Thailand.

E-mail: tkatisart@gmail.com

DOI: 10.4103/pr.pr_116_19
Access this article online Website: www.phcogres.com

Quick Response Code:

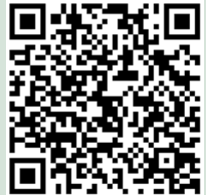

\section{INTRODUCTION}

Bombax ceiba (Bombacaceae), also known as Ngui (in Thai), is found and grown in Africa, Australia, and Asia including Thailand. ${ }^{[1]}$ The pharmacological studies in this plant provided the information that $B$. ceiba exhibits various biological activities such as astringent, cooling, stimulant, diuretic, aphrodisiac, demulcent, and tonic activities. ${ }^{[2]}$

It was found that the young roots of $B$. ceiba have hypoglycemic, hypolipidemic, and hepatoprotective activities and confirm the traditional uses of this plant to manage diabetes and its associated liver toxicity. ${ }^{[3]}$ In addition, the male rat treated with young root extracts of this plant has improved sexual performances and behaviors. ${ }^{[4]}$

The methanolic stem bark extract of this plant has excellent anti-obesity activity in rats induced by a high-fat diet. ${ }^{[5]}$ Bark and seeds powder has hyperlipidemic activity with a reduction in serum and tissue lipid

profiles. ${ }^{[6]}$ The lupeol from stem bark exhibits the inhibitory effect on human umbilical venous endothelial cells (HUVEC) tube formation without affecting the growth of tumor cell lines. ${ }^{[7]}$ It is reported that there are triterpenoid compounds in the stem bark extract, which could be responsible for lowering blood glucose levels. ${ }^{[8]}$

This is an open access journal, and articles are distributed under the terms of the Creative Commons Attribution-NonCommercial-ShareAlike 4.0 License, which allows others to remix, tweak, and build upon the work non-commercially, as long as appropriate credit is given and the new creations are licensed under the identical terms.

For reprints contact: reprints@medknow.com

Cite this article as: Kriintong $\mathrm{N}$, Katisart $\mathrm{T}$. In vitro antioxidant and antidiabetic activities of leaf and flower extracts from Bombax ceiba. Phcog Res 2020;12:194-8. 
The leaf extracts displayed significant wound healing activity. ${ }^{[9]}$ They also showed a remarkable hypoglycemic and hypolipidemic activity which is related to Type 2 diabetes. Moreover, the antidiabetic activity of B. ceiba leaf extracts may due to the antioxidant activity and pancreatic $\beta$-cell histology improvement. ${ }^{[10]}$ The mangiferin in leaf extracts improved the diabetic complications in the kidney and decreased free radicals in meningeal cells. ${ }^{[11]}$ In addition, the leaf extracts exhibit the antianxiety activity ${ }^{[12]}$ The leaf extracts of this plant improved the stress behaviors in animal models. The leaf extracts also increased the antioxidant values in brain tissues of rats. ${ }^{[13]}$

It is reported that the flower extract has an excellent antioxidant activities. ${ }^{[14]}$ The methanolic flower extract of B. ceiba has the protective effects against cytotoxicity in the cell line. ${ }^{[15]}$ The flowers of this plant also could improve liver function in the animal model which may due to its antioxidant potential. ${ }^{[16]}$ The aqueous flower extract prevents against cardiotoxicity. ${ }^{[17]}$ The flower extracts possess a protective effect on the gastric injury. ${ }^{[18]}$ The flower extracts also showed the inhibitory effects on renal cancer cell lines. The biological activity of $B$. ceiba flower extracts may relate to the presence of $ß$-sitosterol and fatty acids. ${ }^{[19]}$ The aqueous methanol flower extract exhibits the hepatoprotective activity. ${ }^{[20]}$

The fruit of $B$. ceiba possesses the lithotriptic activity confirming the use in the treatment of urolithiasis. ${ }^{[21]}$ The fruit extracts also have diuretic activity. ${ }^{[22]}$ The leaf and flower extracts of B. malabaricum which is a synonym of $B$. ceiba possess significant antipyretic ${ }^{[23]}$ and antioxidant activities, respectively. ${ }^{[24]}$

The phytochemical screening revealed that flower extracts of this plant consist of three xanthones and nine flavonoids. ${ }^{[25]}$ Another study found that the flowers comprise ten flavonoids, quercetin, four coumarins, and seven other compounds. ${ }^{[26]}$

For ethnobotanical uses, it was found that androecium of this plant is used as a food ingredient for Indian people. ${ }^{[27]}$ Some parts of this plant are edible that is famous in the Northern part Thailand. People use flowers to cook as curry soup, called "Nam Ngiao" served with rice noodles. ${ }^{[28]}$ However, there are a few scientific reports on the biological activities of leaf and flower of B. ceiba. Therefore, this study was carried out to study the in vitro antioxidant and antidiabetic activities of B. ceiba leaf and flower extracts.

\section{MATERIALS AND METHODS}

\section{Plant preparation and extraction}

Leaf and flower parts of B. ceiba were used for extractions. They were collected from the cultivation area in Phichit Province, Northern part of Thailand. They were washed by running through tap water and then dried in a hot air oven at $40^{\circ} \mathrm{C}$ for $18 \mathrm{~h}$. Then, they were ground as fine power using an electrical grinder. The aqueous extracts were prepared by added $100 \mathrm{~g}$ of dry powder of leaf and flower into $1000 \mathrm{~mL}$ of distilled water and boiled at $100^{\circ} \mathrm{C} 10 \mathrm{~min}$ for three times. The $50 \%$ and $95 \%$ ethanol extracts were prepared by adding $100 \mathrm{~g}$ of dry powder of leaf and flower in $400 \mathrm{~mL}$ of 50\% and 95\% ethanol and macerated for 7 days. The crude residues were filtered using filter paper Whatman No. 1. The filtrates were obtained by removing the solvents in a rotary evaporator and then freeze-dried as a fine powder and kept at $-20^{\circ} \mathrm{C}$ until used.

\section{Phytochemical screening}

The leaf and flower extracts of $B$. ceiba were screened for the presence of alkaloids, flavonoids, coumarins, anthraquinones, saponins, tannins, terpenoids, steroids, and cardiac glycosides. The experiment was performed using standard qualitative methods described by Wadood et al. ${ }^{[29]}$ with some modifications.

\section{Determination of total phenolic content}

The total phenolic content (TPC) was investigated by Folin Ciocalteu's method and described by Singleton et al. ${ }^{[30]}$ with some modifications. Briefly, $100 \mu \mathrm{L}$ of the gallic acid solution (standard) and samples was prepared in a $10 \mathrm{~mL}$ test tube. Five hundred microliter of the Folin-Ciocalteu's reagent was added and mixed. One hundred microliter distilled water was used as a blank. After that, $400 \mu \mathrm{L}$ of $7.5 \% \mathrm{Na}_{2} \mathrm{CO}_{3}$ solution was added in each tube and mixed well. The samples were left to react at $25^{\circ} \mathrm{C}$ for $30 \mathrm{~min}$ in the dark room. Ultraviolet-visible (UV-Vis) spectrophotometer was used to measure the absorbance at $765 \mathrm{~nm}$. Five replications were performed in each treatment. The TPC value was expressed as mg gallic acid equivalents (GAE) per g sample.

\section{Determination of total flavonoid content}

The total flavonoid content (TFC) was investigated by a colorimetric method and described by Zhishen et al ${ }^{[31]}$ with some modifications. One hundred microliter of the quercetin solution and samples was prepared in a $10 \mathrm{~mL}$ test tube. Four hundred micro liter of $2.5 \% \mathrm{NaNO}_{2}$ was added and mixed. The blank used $100 \mu \mathrm{L}$ distilled water instead of the standard solution and samples. Thereafter, $500 \mu \mathrm{L}$ of $5 \% \mathrm{AlCl}_{3}$ solution and $2000 \mu \mathrm{L}$ of distilled water were added. The samples were allowed to react at $25^{\circ} \mathrm{C}$ for $10 \mathrm{~min}$. The absorbance was measured using UV-Vis spectrophotometer at $415 \mathrm{~nm}$. The experiments were repeated five times. The TFC value was expressed as mg quercetin equivalents (QEs) in per g sample.

\section{Determination of in vitro antioxidant activity 2,2-diphenyl-1-picrylhydrazyl radical scavenging assay}

2,2-diphenyl-1-picrylhydrazyl (DPPH) radical scavenging assay was carried out by the modified method described by Brand-Williams et al. ${ }^{[32]}$ One millimeter DPPH was dissolved in distilled water. One hundred microliter of the standard solution and samples was prepared. Nine hundred microliter of $1 \mathrm{mM}$ DPPH solution was added and allowed to react for $30 \mathrm{~min}$ at $25^{\circ} \mathrm{C}$. The absorbance was measured at $515 \mathrm{~nm}$ to determine the DPPH radical inhibitory activity of the extracts. The experiments were repeated five times. In the present study, the positive controls were ascorbic acid and trolox. The results were expressed as a percentage inhibition of DPPH calculated from the following formula.

$\%$ radical inhibition $=\left(\left[\mathrm{A}_{0}-\mathrm{A}_{1}\right] / \mathrm{A}_{0}\right) \times 100$

Whereas, $A_{0}=$ Absorbance of blank, $A_{1}=$ Absorbance of sample

Half-maximal inhibitory concentration $\left(\mathrm{IC}_{50}\right.$ ) was calculated from the calibration curve by linear regression.

\section{2,2-azinobis-(3-ethylbenzothaizoline-6-sulphonate radical scavenging assay}

The procedure described by Re et al. ${ }^{[33]}$ was followed. Seven millimeter of 2,2-azinobis-(3-ethylbenzothaizoline-6-sulphonate (ABTS) was dissolved in $\mathrm{K}_{2} \mathrm{~S}_{2} \mathrm{O}_{8}$ solution with $\mathrm{pH}$ 7.4. The ABTS solution was left at $25^{\circ} \mathrm{C}$ for $16 \mathrm{~h}$ in the dark and then dilute ABTS solution by distilled water in ratio 1:50, respectively. Aliquots of $100 \mu \mathrm{L}$ of the standard solution and samples were prepared in a $10 \mathrm{~mL}$ test tube and $900 \mu \mathrm{l}$ of ABTS solution was added and allowed to react $25^{\circ} \mathrm{C}$ for $6 \mathrm{~min}$. The ABTS inhibition was measured by the reduction in absorbance at $734 \mathrm{~nm}$. The positive control was ascorbic acid and trolox, while distilled water was used as a negative control and as blank. $\mathrm{IC}_{50}$ was determined from the standard curve.

\section{Ferric reducing antioxidant power radical scavenging assay}

Ferric reducing antioxidant power (FRAP) assay was adapted from Benzie and Strain ${ }^{[34]}$ with some modifications. The FRAP reagent

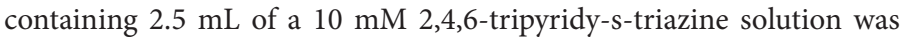
prepared in $40 \mathrm{mM} \mathrm{HCl}$ plus $2.5 \mathrm{~mL}$ of $20 \mathrm{mM} \mathrm{FeCl}_{3}$ and $25 \mathrm{~mL}$ of $0.3 \mathrm{mM}$ acetate buffer, $\mathrm{pH}$ 3.6. The reagent was prepared freshly and 
incubated at $37^{\circ} \mathrm{C}$ for $60 \mathrm{~min}$. One hundred microliter of the standard solution and samples was prepared. $900 \mu \mathrm{L}$ of FRAP solution was added and allowed to react $25^{\circ} \mathrm{C}$ for $5 \mathrm{~min}$. The experiments were repeated five times. Trolox was used as a positive control. The absorbance was measured at $593 \mathrm{~nm}$. The inhibition of a ferric-tripyridyltriazine value was expressed as mg trolox equivalents (TEs) per g sample.

\section{Determination of in vitro antidiabetic activities $\alpha$-Glucosidase inhibition assay}

The ability of $B$. ceiba extract to inhibit $\alpha$-glucosidase that was performed using the colorimetric methods was described in Dong et al's study ${ }^{[35]}$ with some modifications. One hundred microliter of the standard solution and samples was prepared. One hundred microliter of $1 \mathrm{unit} / \mathrm{mL} \alpha$-glucosidase in $0.1 \mathrm{M}$ potassium phosphate buffer $(\mathrm{pH} 6.8)$ was prepared. After incubation at $37^{\circ} \mathrm{C}$ for $20 \mathrm{~min}, 100 \mu \mathrm{L}$ of $2 \mathrm{mM}$ pNP-G in the buffer was added; then, the solution was incubated at $37^{\circ} \mathrm{C}$ for $20 \mathrm{~min}$. Three hundred and twenty microliter of $1 \mathrm{mM} \mathrm{Na}_{2} \mathrm{CO}_{3}$ in the buffer was added to stop the reaction. The absorbance was measured at $405 \mathrm{~nm}$. Acarbose was used as a positive control, while a $0.1 \mathrm{M}$ potassium phosphate buffer was used as a negative control. $\mathrm{IC}_{50}$ was calculated from the standard curve. The results were expressed as percentage inhibition of $\alpha$-glucosidase compared to the controls.

$\%$ inhibition $=([\mathrm{A} 0-\mathrm{A} 1] / \mathrm{A} 0) \times 100$

Whereas, $A_{0}=$ Absorbance of blank, $A_{1}=$ Absorbance of sample

$\mathrm{IC}_{50}$ values were calculated with a standard curve plotted by inhibition percentage against the concentration.

\section{$\alpha$-Amylase inhibition assay}

The $\alpha$-amylase inhibition protocol was adapted from the method described by Akkarachaiyasit. ${ }^{[36]} \alpha$-Amylase was dissolved in sodium phosphate buffer $\mathrm{pH} 6.9$ to adjust a concentration of $3 \mathrm{unit} / \mathrm{mL}$ solution. Rice starch $(1 \% \mathrm{w} / \mathrm{v})$ was dissolved in hot water. The $\alpha$-amylase $150 \mu \mathrm{L}$, leaf and flower extract of B. ceiba or acarbose (standard) $20 \mu \mathrm{L}, 180$ $\mu \mathrm{L}$ of sodium phosphate buffer $\mathrm{pH} 6.9$, and $150 \mu \mathrm{L}$ of starch solution were added. The solution was incubated at $37^{\circ} \mathrm{C}$ for $10 \mathrm{~min}$. Then, $1 \%$ 3,5-dinitrosalicylic acid (DNS) $500 \mu \mathrm{L}$ was added. Thereafter, the solution was decocted for $10 \mathrm{~min}$. Five hundred microliter sodium potassium tartrate was added. The inhibition of $\alpha$-amylase activity was measured at a wavelength of $540 \mathrm{~nm}$. Acarbose was used as a positive control and $0.1 \mathrm{M}$ potassium phosphate buffer as a negative control and as blank. $\mathrm{IC}_{50}$ was determined from the standard curve.

\section{Statistical analysis}

All data were expressed as mean \pm standard error of mean with $n=5$. The difference among means was tested using one-way analysis of variance followed by Duncan multiple range test. $P<0.05$ was considered statistically significance. Statistical analysis was carried out using SPSS Statistics version 23.0 (IBM; New Orchard Road, Armonk, New York, United States).

\section{RESULTS}

\section{Phytochemical constituents}

Qualitative phytochemical screening of leaf and flower extract of B. ceiba demonstrated that the extracts contain alkaloids, flavonoids, glycosides, and coumarins. However, there are no anthraquinone and steroid in this plant [Table 1].

\section{Total phenolic and flavonoid content}

EFE of $B$. ceiba obviously showed the highest TPC and TFC $(2.73 \pm 0.064 \mathrm{mg} \mathrm{GAE} / \mathrm{g}, 28.25 \pm 2.33 \mathrm{mg}$ QE/g, respectively), while ALE showed the lowest TPC and TFC $(0.09 \pm 0.002 \mathrm{mg}$ $\mathrm{GAE} / \mathrm{g}, 1.34 \pm 0.09 \mathrm{mg} \mathrm{QE} / \mathrm{g}$, respectively) compared with other extracts [Table 2].

\section{In vitro antioxidant activities \\ 2,2-diphenyl-1-picrylhydrazyl radical scavenging activity}

The DPPH radical scavenging activities of $B$. ceiba ( $\mathrm{IC}_{50}$ values) are shown in Table 3. It was found that both leaf extracts $(95 \%$ ethanol leaf extract [ELE] $)\left(\mathrm{IC}_{50}=0.012 \pm 0.0003 \mathrm{mg} / \mathrm{mL}\right)$ and flower extracts $(50 \%$ ethanol flower extract $[\mathrm{HEFE}])\left(\mathrm{IC}_{50}=0.019 \pm 0.0002 \mathrm{mg} / \mathrm{mL}\right)$ exhibited strong radical scavenging activity compared to those of the standard trolox $\left(\mathrm{IC}_{50}=0.016 \pm 0.0011 \mathrm{mg} / \mathrm{mL}\right)$. However, the extracts had the less potent antioxidant activity than those of the standard ascorbic acid $\left(\mathrm{IC}_{50}=0.004 \pm 0.0002 \mathrm{mg} / \mathrm{mL}\right)$.

\section{2,2-azinobis-(3-ethylbenzothaizoline-6-sulphonate radical scavenging activity}

The result indicated that the plants extracts inhibited the ABTS + radicals; the lowest $\mathrm{IC}_{50}$ values were found in $\operatorname{ELE}(0.009 \pm 0.0005 \mathrm{mg} / \mathrm{mL})$, while highest $\mathrm{IC}_{50}$ values were found in $\operatorname{AFE}(0.197 \pm 0.0011 \mathrm{mg} / \mathrm{mL})$, as shown in Table 3. However $\mathrm{IC}_{50}$ values of ELE were almost similar to those of the standard trolox $(0.009 \pm 0.0006 \mathrm{mg} / \mathrm{mL})$.

\section{Ferric reducing antioxidant power radical scavenging activity}

The reducing power of the extracts of different solutions is shown in Table 3. EFE obviously showed the highest ability to reduce $\mathrm{Fe}^{2+}(349.27 \pm 35.16 \mathrm{mg} \mathrm{TE} / \mathrm{g})$, while ALE $(30.04 \pm 0.64 \mathrm{mg} \mathrm{TE} / \mathrm{g})$ showed the lowest compared to other extracts $(P<0.05)$.

\section{In vitro antidiabetic activities $\alpha$-Glucosidase inhibitory activity}

The $\mathrm{IC}_{50}$ values of $\alpha$-glucosidase inhibition of EFE, AFE, and HEFE were $0.001 \pm 0.0012,0.002 \pm 0.0006$, and $0.003 \pm 0.0004 \mathrm{mg} / \mathrm{mL}$, respectively. The high $\mathrm{IC}_{50}$ values of $\alpha$-glucosidase inhibition of HELE, ALE, and ELE of $B$. ceiba leaves were $0.121 \pm 0.0022,0.175 \pm 0.0027$, and $0.187 \pm 0.0089 \mathrm{mg} / \mathrm{mL}$, respectively, as shown in Table 4 .

\section{$\alpha$-Amylase inhibitory activity}

In this study, the $\mathrm{IC}_{50}$ value of $\alpha$-amylase inhibition of $\mathrm{EFE}$ was

Table 1: Phytochemical constituent's different solvent of Bombax ceiba extracts

\begin{tabular}{|c|c|c|c|c|c|c|c|c|c|}
\hline $\begin{array}{l}\text { Bombax } \\
\text { ceiba extract }\end{array}$ & Alkaloid & Flavonoid & $\begin{array}{c}\text { Anthra } \\
\text { quinone }\end{array}$ & Coumarin & Saponin & Tannin & Terpenoid & Steroid & $\begin{array}{l}\text { Cardiac } \\
\text { glycoside }\end{array}$ \\
\hline ALE & + & + & - & + & - & + & - & - & + \\
\hline $\mathrm{AFE}$ & - & + & - & + & - & - & - & - & - \\
\hline HELE & + & + & - & + & + & + & - & - & + \\
\hline HEFE & + & + & - & + & - & - & - & - & - \\
\hline ELE & + & + & - & + & + & + & - & - & + \\
\hline EFE & + & + & - & - & - & - & + & - & - \\
\hline
\end{tabular}

-: Absence; +: Presence; ALE: Aqueous leaf extract; AFE: Aqueous flower extract; HELE: 50\% ethanol leaf extract; HEFE: 50\% ethanol flower extract; ELE: 95\% ethanol leaf extract; EFE: 95\% ethanol flower extract 
Table 2: Total phenolic content and total flavonoid content of Bombax ceiba extracts

\begin{tabular}{lcc}
\hline Bombax ceiba extract & TPC $^{\mathrm{A}}(\mathrm{mg} \mathrm{GAE} / \mathrm{g})$ & $\mathrm{TFC}^{\mathrm{B}}(\mathrm{mg} \mathrm{QE} / \mathrm{g})$ \\
\hline ALE & $0.09 \pm 0.002^{\mathrm{a}}$ & $1.34 \pm 0.09^{\mathrm{a}}$ \\
AFE & $0.82 \pm 0.014^{\mathrm{b}}$ & $8.71 \pm 0.59^{\mathrm{b}}$ \\
HELE & $1.01 \pm 0.013^{\mathrm{c}}$ & $13.22 \pm 3.15^{\mathrm{c}}$ \\
HEFE & $1.15 \pm 0.023^{\mathrm{d}}$ & $16.33 \pm 0.49^{\mathrm{d}}$ \\
ELE & $1.67 \pm 0.026^{\mathrm{e}}$ & $16.87 \pm 2.67^{\mathrm{d}}$ \\
EFE & $2.73 \pm 0.064^{\mathrm{f}}$ & $28.25 \pm 2.33^{\mathrm{e}}$ \\
\hline
\end{tabular}

${ }^{\mathrm{a}-\mathrm{f}}$ Different letters in the same row indicate significance $(P<0.05) ;{ }^{A}$ Results were expressed as mean $\pm \mathrm{SD}(n=5)$ and as mg GAE in $1 \mathrm{~g}$ sample; ${ }^{\mathrm{B}}$ Results were expressed as mean $\pm \mathrm{SD}(n=5)$ and as $\mathrm{mg} \mathrm{QE}$ in $1 \mathrm{~g}$ sample. TPC: Total phenolic content; TFC: Total flavonoid content; ALE: Aqueous leaf extract; AFE: Aqueous flower extract; HELE: 50\% ethanol leaf extract; HEFE: 50\% ethanol flower extract; ELE: 95\% ethanol leaf extract; EFE: 95\% ethanol flower extract; SD: Standard deviation

Table 3: In vitro antioxidant activities of Bombax ceiba extracts

\begin{tabular}{lccc}
\hline $\begin{array}{l}\text { Bombax } \\
\text { ceiba extract }\end{array}$ & \multicolumn{3}{c}{ Antioxidant activity } \\
\cline { 2 - 4 } & $\begin{array}{c}\text { DPPH } \\
\left(\mathrm{IC}_{50^{\prime}}, \mathrm{mg} / \mathrm{mL}\right)\end{array}$ & $\begin{array}{c}\text { ABTS } \\
\left(\mathrm{IC}_{50^{\prime}}, \mathrm{mg} / \mathrm{mL}\right)\end{array}$ & $\begin{array}{c}\text { FRAP } \\
(\mathrm{mg} \mathrm{TE} / \mathrm{g})\end{array}$ \\
\hline ALE & $0.114 \pm 0.0068^{\mathrm{a}}$ & $0.096 \pm 0.0104^{\mathrm{a}}$ & $30.04 \pm 0.64^{\mathrm{a}}$ \\
AFE & $0.025 \pm 0.0004^{\mathrm{b}}$ & $0.019 \pm 0.0011^{\mathrm{b}}$ & $112.14 \pm 10.50^{\mathrm{b}}$ \\
HELE & $0.022 \pm 0.0006^{\mathrm{c}, \mathrm{d}}$ & $0.018 \pm 0.0002^{\mathrm{b}}$ & $113.20 \pm 12.72^{\mathrm{b}}$ \\
HEFE & $0.019 \pm 0.0002^{\mathrm{d}, \mathrm{e}}$ & $0.037 \pm 0.0003^{\mathrm{c}}$ & $102.50 \pm 6.26^{\mathrm{b}}$ \\
ELE & $0.012 \pm 0.0003^{\mathrm{e}}$ & $0.009 \pm 0.0005^{\mathrm{d}}$ & $94.55 \pm 1.79^{\mathrm{b}}$ \\
EFE & $0.024 \pm 0.0002^{\mathrm{b}, \mathrm{c}}$ & $0.029 \pm 0.0012^{\mathrm{e}}$ & $349.27 \pm 35.16^{\mathrm{c}}$ \\
Trolox & $0.016 \pm 0.0011^{\mathrm{d}}$ & $0.009 \pm 0.0006^{\mathrm{d}}$ & \\
Ascorbic & $0.004 \pm 0.0002^{\mathrm{f}}$ & $0.002 \pm 0.0000^{\mathrm{f}}$ & \\
\hline
\end{tabular}

${ }^{\mathrm{a}-\mathrm{g}}$ Different letters in the same row indicate significance $(P<0.05)$; Results were expressed as mean $\pm \mathrm{SD}(n=5)$ and as $\mathrm{mg} \mathrm{TE}$ in $1 \mathrm{~g}$ sample. Results were expressed as mean $\pm \mathrm{SD}(n=5)$. $\mathrm{IC}_{50}$ : Half-maximal inhibitory concentration; ALE: Aqueous leaf extract; AFE: Aqueous flower extract; HELE: 50\% ethanol leaf extract; HEFE: 50\% ethanol flower extract; ELE: 95\% ethanol leaf extract; EFE: 95\% ethanol flower extract; DPPH: 2,2-diphenyl-1-picrylhydrazyl; ABTS: 2,2-azinobis-(3-ethylbenzothaizoline-6-sulphonate; FRAP: Ferric reducing antioxidant power; SD: Standard deviation

Table 4: $\alpha$-Glucosidase and a-amylase inhibitory activities of Bombax ceiba extracts

\begin{tabular}{lcc}
\hline \multirow{2}{*}{$\begin{array}{l}\text { Bombax } \\
\text { ceiba extract }\end{array}$} & \multicolumn{2}{c}{ Antidiabetic activity } \\
\cline { 2 - 3 } & a-glucosidase $\left(\mathrm{IC}_{50^{\prime}} \mathrm{mg} / \mathrm{mL}\right)$ & a-amylase $\left(\mathrm{IC}_{50^{\prime}} \mathrm{mg} / \mathrm{mL}\right)$ \\
\hline ALE & $0.175 \pm 0.0027 \mathrm{a}$ & $\mathrm{ND}$ \\
AFE & $0.002 \pm 0.0006 \mathrm{~b}$ & $\mathrm{ND}$ \\
HELE & $0.121 \pm 0.0022 \mathrm{c}$ & $\mathrm{ND}$ \\
HEFE & $0.003 \pm 0.0004 \mathrm{~b}$ & $0.0024 \pm 0.0002 \mathrm{a}$ \\
ELE & $0.187 \pm 0.0089 \mathrm{~d}$ & $0.0012 \pm 0.0009 \mathrm{~b}$ \\
EFE & $0.001 \pm 0.0012 \mathrm{~b}$ & $0.0002 \pm 0.0001 \mathrm{c}$ \\
Acarbose & $0.201 \pm 0.0212 \mathrm{e}$ & $0.0020 \pm 0.0004 \mathrm{a}$ \\
\hline
\end{tabular}

${ }^{a-d}$ Different letters in the same row indicate significance $(P<0.05)$. Results were expressed as mean $\pm \mathrm{SD}(n=5) . \mathrm{IC}_{50}$ : Half-maximal inhibitory concentration; ALE: Aqueous leaf extract; AFE: Aqueous flower extract; HELE: 50\% ethanol leaf extract; HEFE: 50\% ethanol flower extract; ELE: 95\% ethanol leaf extract; EFE: 95\% ethanol flower extract; ND: Not determined; SD: Standard deviation

$0.0002 \pm 0.0001 \mathrm{mg} / \mathrm{mL}$ followed by $\operatorname{ELE}(0.0012 \pm 0.0009 \mathrm{mg} / \mathrm{mL})$ and HEFE $(0.0024 \pm 0.0002 \mathrm{mg} / \mathrm{mL})$, as shown in Table 4 .

\section{DISCUSSION}

B. ceiba extracts possess various biological activities such as antioxidant, anti-inflammatory, and antimicrobial activities. In addition, the extracts from this plant exhibit their medicinal values in the treatment of diabetes and hyperglycemia. ${ }^{[37]}$ Flower parts of B. ceiba have been used as a food ingredient among Thai people. However, there are a few scientific reports on their biological and pharmacological activities. In this present study, it was found that leaf and flower extracts of B. ceiba contain phytochemicals including alkaloids, flavonoids, coumarins, saponins, tannins, terpenoids, and cardiac glycosides. Moreover, the high total phenolic and flavonoid contents were found in flower extracts. The flower extracts also exhibit the high antioxidant and antidiabetic activities in vitro. It was reported that there are phytochemical constituents including isovanillic acid, mangiferin, protocatechuic acid, rutin, quercetin, and apigenin in this plant. ${ }^{[15]}$ However, the TPCs of aqueous and HEFEs in the present study are less than those in the flower extracts from $B$. malabaricum which is claimed to be a synonym of $B$. ceiba. This demonstrates that the flowers of B. malabaricum have remarkable antioxidant activity. ${ }^{[24]}$ In the present study, it was found that AFE and HEFE has higher inhibitory activity against DPPH and ABTS free radical than those of ALE and HELE. However, EFE has lower antioxidant activity than those of ELE. Due to the solvent's ability with different polarity, ethanol may be a suitable solvent for the extraction of polyphenol and less toxic to human health. ${ }^{[38]}$ ABTS scavenging activity of $B$. ceiba suggests that the phytochemicals within the extracts donate electron/hydrogen resulting in the reduction of oxidative stress. ${ }^{[39]}$ The reducing power of the extracts to reduce $\mathrm{Fe}^{2+}$ is strong, and it depends on total phenolic and flavonoid contents. This result is similar to the previous study that flavonoid compound is secondary natural product metabolites responses for the antioxidant ability. ${ }^{[40]}$ In terms of in vitro antidiabetic activities, $B$. ceib $a$ flower extracts have higher $\alpha$-glucosidase and $\alpha$-amylase inhibitory activity than those of the standard acarbose. This suggests that the extracts are rich in flavonoids and phenolics which can inhibit $\alpha$-glucosidase and $\alpha$-amylase activity and potential to contribute to the management of diabetes. ${ }^{[41]}$ These results are similar to previous report that $50 \%$ ethanolic extract of stem bark and flowers of B. ceiba possesses hypoglycemic activity and mangiferin is responsible for the lowering of fasting blood glucose level. ${ }^{[42]}$

\section{CONCLUSION}

The leaf and flower extracts of $B$. ceiba showed a significant antioxidant capacity against $\mathrm{DPPH}, \mathrm{ABTS}^{+}$, and ferric-tripyridyltriazine radicals. The flower extracts exhibit high antioxidant and antidiabetic activities in vitro. These pharmacological potentials may be due to the presence of phenolic and flavonoid compound. These findings confirm the benefit of ethnobotanical uses of this plant.

\section{Acknowledgements}

The authors would like to acknowledge the Department of Biology, Faculty of Science, Mahasarakham University for laboratory equipment for completion of this research, and the Faculty of Medicine, Mahasarakham University, Thailand, for supporting facilities. This research was financially supported by the scholarship project of the promotion of science and mathematics talented teacher and Mahasarakham University (Grant year 2020).

\section{Financial support and sponsorship}

This research was financially supported by Faculty of Science, Mahasarakham University.

\section{Conflicts of interest}

There are no conflicts of interest.

\section{REFERENCES}

1. Jain V, Verma SK. Springer Briefs in Pharmacology and Toxicology. In: Pharmacology of Bombax ceiba Linn. Heidelberg, New York, Dordrecht, 
London: Springer Science \& Business Media; 2012. p. 12-45.

2. Meenakshi SC, Beldal BS, Londonkar RL. Review on ethnobotany phytoconstituents and phytopharmacology of Bombax ceiba Linn. Int J Pharm Biol Sci 2019;9:1061-6

3. Sharmin R, Islam MU, Joarder HH, Alamgir M, Mostofa G, Alam K. Antidiabetic and hepatoprotective activities of Bombax ceiba young roots in alloxan-induced diabetic mice. J Nutrition Health Food Sci 2018;6:1-7.

4. Bhargava C, Thakur M, Yadav SK. Effect of Bombax ceiba L. on spermatogenesis, sexual behaviour and erectile function in male rats. Andrologia 2012;44 Suppl 1:474-8.

5. Gupta $P$, Goyal R, Chauhan $Y$, Sharma PL. Possible modulation of FAS and PTP-1B signaling in ameliorative potential of Bombax ceiba against high fat diet induced obesity. BMC Complement Altern Med 2013;13:281.

6. Singh A, Chauhan ES, Singh OP. Anti-hyperlipidaemic effect of Bombax ceiba bark and seeds powder on albino wistar rats. World J Pharm Pharm Sci 2018;7:1259-76.

7. You YJ, Nam NH, Kim Y, Bae KH, Ahn BZ. Antiangiogenic activity of lupeol from Bombax ceiba. Phytother Res 2003;17:341-4.

8. Bhavsar CJ, Talele GS. Potential anti-diabetic activity of Bombax ceiba. Bangladesh J Pharm 2013;8:102-6.

9. Kumar A, Shamim S. Evaluation of wound healing activity of leaves of Bombax ceiba. J Med Sci Clin Res 2018;6:119-26.

10. Xu GK, Qin XY, Wang GK, Xie GY, Li XS, Sun CY, et al. Antihyperglycemic, antihyperlipidemic and antioxidant effects of standard ethanol extract of Bombax ceiba leaves in high-fat-diet- and streptozotocin-induced Type 2 diabetic rats. Chin J Nat Med 2017;15:168-77.

11. $X u$ GK, Sun CY, Oin $X Y$, Han Y, Li Y, Xie GY, et al. Effects of ethanol extract of Bombax ceiba leaves and its main constituent mangiferin on diabetic nephropathy in mice. Chin J Nat Med 2017;15:597-605.

12. Alsayari A, Ghazwani M, Almaghaslah D, Alhamhoom $Y$, Ahmed R, Saeed W, et al. Bombax ceiba: A potential anti-anxiety drug. Pharmacog $J$ 2018;10:712-4.

13. Mostafa NM. $\beta$-Amyrin rich Bombax ceiba leaf extract with potential neuroprotective activity against scopolamine-induced memory impairment in rats. Rec Nat Prod 2018;12:480-92

14. Vieira TO, Said A, Aboutabl E, Azzam M, Creczynski-Pasa TB. Antioxidant activity of methanolic extract of Bombax ceiba. Redox Rep 2009;14:41-6.

15. Nakashima S, Oda $Y$, Ogawa $Y$, Nakamura $S$, Uno $M$, Kishimoto $M$, et al. Protective effects of compounds in Bombax ceiba flower on benzo[a] pyrene-induced cytotoxicity. Nat Prod Commun 2018;13:561-4.

16. Wanjari MM, Gangoria R, Dey YN, Gaidhani SN, Pandey NK, Jadhav AD. Hepatoprotective and antioxidant activity of Bombax ceiba flowers against carbon tetrachloride-induced hepatotoxicity in rats. Hepatoma Res 2016;2:144-50

17. Patel SS, Verma NK, Rathore B, Nayak G, Singhai AK, Singh P. Cardioprotective effect of Bombax ceiba flowers against acute adriamycin-induced myocardial infarction in rats. Rev Bras de Farmacognosia 2011;21:704-9.

18. Barakat MM, El-Boghdady NA, Farrag EK, Said AA, Shaker SE. Protective and curative effects of Bombax ceiba flower and Ziziphus spina christi fruit extracts on gastric ulcer. J Biol Sci 2019;19:161-72.

19. Tundis R, Rashed K, Said A, Menichini F, Loizzo MR. In vitro cancer cell growth inhibition and antioxidant activity of Bombax ceiba (Bombacaceae) flower extracts. Nat Prod Commun 2014;9:691-4.

20. Arafa AF, Foda DS, Mahmoud AH, Metwally NS, Farrag AR. Bombax ceiba flowers extract ameliorates hepatosteatosis induced by ethanol and relatively moderate fat diet in rats. Toxicol Rep 2019;6:401-8.

21. Gadge NB, Jalalpure SS. Curative treatment with extracts of Bombax ceiba fruit reduces risk of calcium oxalate urolithiasis in rats. Pharm Biol 2012;50:310-7.

22. Jalalpure SS, Gadge NB. Diuretic effects of young fruit extracts of Bombax ceiba L. In rats. Indian J Pharm Sci 2011;73:306-11.

23. Hossain E, Mandal SC, Gupta JK. Phytochemical screening and in vivo antipyretic activity of the methanol leaf-extract of Bombax malabaricum DC (Bombacaceae). Trop J Pharm Res 2011;10:55-60.

24. Yu YG, He QT, Yuan K, Xiao XL, Li XF, Liu DM, et al. In vitro antioxidant activity of Bombax malabaricum flower extracts. Pharm Biol 2011;49:569-76.

25. El-Toumy SA, Hawas UW, Taie HA. Xanthones and antitumor activity of Bombax ceiba against ehrlich ascites carcinoma cells in mice. Chem Nat Comp 2013;49:945-50.

26. Joshi KR, Devkota HP, Yahara S. Chemical analysis of flowers of Bombax ceiba from Nepal. Nat Prod Commun 2013;8:583-4.

27. Depani P, Gadhvi K, Vyas S. Ethnobotanical potential and phytochemical screening of Bombax ceiba L. Eur J Med Plants 2019;29:1-8.

28. Thongmee O, Rodhetbhai C, Siltragool W. Lanna food: The cultural management strategy for the creative economy development. Silpakorn Univ J Soc Sci Humanit Art 2015;15:105-19.

29. Wadood A, Ghufran M, Jamal SB, Naeem M, Khan A, Ghaffar R, et al Phytochemical analysis of medicinal plants occurring in local area of Mardan. Biochem Anal Biochem 2013;2:1-4.

30. Singleton VL, Orthofer R, Lamuela-Raventos RM. Analysis of total phenols and other oxidation substrates and antioxidants by means of Folin-Ciocalteu reagent. Am J Enol 1999;299:152-78.

31. Zhishen J, Mengcheng T, Jianming W. The determination of flavonoid contents in mulberry and their scavenging effects on superoxide radicals. Food Chem 1999;64:555-9.

32. Brand-Williams W, Cuvelier ME, Berset C. Use of a free radical method to evaluate antioxidant activity. Lebensm-Wiss u-Technol 1995;28:25-30.

33. Re R, Pellegrini N, Proteggente A, Pannala A, Yang M, Rice-Evans C. Antioxidant activity applying an improved ABTS radical cation decolorization assay. Free Radic Biol Med 1999;26:1231-7.

34. Benzie IF, Strain JJ. The ferric reducing ability of plasma (FRAP) as a measure of "antioxidant power": The FRAP Assay. Analyt Biochem 1996;239:70-6.

35. Dong HQ, Li M, Zhu F, Liu FL, Huang JB. Inhibitory potential of trilobatin from Lithocarpus polystachyus Rehd against $\alpha$-glucosidase and $\alpha$-amylase linked to type 2 diabetes. Food Chem 2012;130:261-6.

36. Akkarachaiyasit S. Alpha-amylase inhibitory activity and antihyperglycemic effects of cyaniding and its derivatives. Chulalongkorn University Thesis for Master of Science Degree in Pharmacology; 2008. p. 48-9.

37. Antil V, Sinha BN, Pandey A, Diwan A, Saini P. Bombax malabaricum: A salutary boon. Int J Pharm Invest 2013;3:17-28.

38. Do QD, Angkawijaya AE, Tran-Nguyen PL, Huynh LH, Soetaredjo FE, Ismadji S, et al. Effect of extraction solvent on total phenol content, total flavonoid content, and antioxidant activity of Limnophila aromatica. J Food Drug Anal 2014;22:296-302

39. Afsar T, Razak S, Khan MR, Mawash S, Almajwal A, Shabir M, et al. Evaluation of antioxidant, anti-hemolytic and anticancer activity of various solvent extracts of Acacia hydaspica R. Parker aerial parts. BMC Complement Altern Med 2016;16:258.

40. Prior RL, Cao GH, Martin A, Sofic E, McEwen J, O'Brien C, et al. Antioxidant capacity as influenced by total phenolic and anthocyanin content, maturity and variety of Vaccinium species. J Agric Food Chem 1998;46:2686-93.

41. Tadera K, Minami Y, Takamatsu K, Matsuoka T. Inhibition of alpha-glucosidase and alpha-amylase by flavonoids. J Nutr Sci Vitaminol (Tokyo) 2006;52:149-53.

42. Jain V, Verma SK. Assessment of credibility of some folk medicinal claims on Bombax ceiba L. Indian J Trad Knowl 2014;13:87-94. 